\title{
CHARACTER BUILDING BASED ON INTELLIGENCE AND KEBUDILUHURAN
}

\author{
Amin AMINUDIN ${ }^{*}$, Nawiroh VERA ${ }^{2}$, Umaimah WAHID ${ }^{3}$, and Hadiono AFDJANI ${ }^{4}$ \\ ${ }^{1}$ Faculty of Communication Sciences, Budi Luhur University, Indonesia \\ ${ }^{2-4}$ Faculty of Communication Sciences, Budi Luhur University, Indonesia \\ *amin.aminudin@budiluhur.ac.id
}

\begin{abstract}
A personality that individuals have formed can increase their self-confidence. The self-confidence influences communication style. Therefore, communication skills and an individual's personality are interconnected with each other. The formulation in this service is how to introduce the foster youth of the National Education Care Foundation located in Ciledug for efforts to build character and personality and the source comes from noble values (kebudiluhuran)? To what extent the basic leadership and organizational skills are inculcated in the foster youth of the National Education Care Foundation located in Ciledug, and therefore, they will become a generation that can develop their best potential? The purpose of this service is to introduce persuasively to the foster youth of the National Education Care Foundation located in Ciledug, on ways to build the character and personality through the introduction of noble values (kebudiluhuran), to develop basic skills in effective communication. The methods in this service are observation, interviews and teaching. The results of this service are obtained in a kind of providing an understanding of communication skills and abilities, and lecturers have strategic positions. As intellectuals, lecturers have a moral responsibility to contribute to the surrounding community. The target community for this service program are the foster youths of the National Education Care Foundation located in Ciledug, Tangerang.
\end{abstract}

Keywords: Character Building, Intelligence, Communication, Kebudiluhuran

\section{BACKGROUND}

As talking about youth it will never end to be discussed. Youth always color every effort of a nation. They take part in the history and progress of a nation. It can be said that the progress or decline of a nation's development lies in the struggle and participation of its youth. In many countries, youth have become actors who play an important role in reducing disaster risks because they are considered very effective in a pragmatic way. Shofa (2016) explains that the progress achieved from the youth existence illustrates the progress of a nation (Pradika et al., 2018).

Indonesia's independence was successfully wrested from the hands of the colonizers through the persistent struggle of the youth with their lives at stake. The Indonesian youth movements also supported it both openly and secretly and therefore, it inflamed the spirit of unity and integrity in Indonesian society at that time. What about now when the Indonesian people are independent? Of course, the role of youth remains needed, particularly in an effort to advance this nation as an advanced and prosperous nation. The post-independence youths remain patriots of the nation whose struggle is desperately needed through positive real work.

As supporting the independence of the nation and state, it is definitely integral to the youth personality. With a personality that has been formed, it can increase an individual's self-confidence. The self-confidence affects communication style. Therefore, an individual's communication skills and personality closely relate to each other. According to Hafied Changara, communication skills are the ability of an individual to convey or send messages to the audience (the recipients of the message). Furthermore, according to Anwar Arifin, communication ability is an individual's skill in conveying a clear message and easy to understand by the recipients of the message. (Cangara, 2014)
Kinichi and Kreitner (2003) define it; Personality is defined as the combination of stable physical and mental characteristics that give the individual his or her identity. This understanding explains that the Personality is a combination of mental characteristics with physical stability that gives identity to individuals. Personality is a natural or natural trait possessed by each individual to interact with others (Simbolon, 2008).

One of personality formation is through a means of communication, because in the terminology, communicationis the process of conveying statements or messages from one person to another. It can be interpreted that those involved in communication are humans. Humans as social beings need other humans to interact. In interacting between one human and another human they require communication. Communication between humans (Human Communication) is frequentlly referred to as social communication. (Onong uchjana Effendy, 2006).

Interpersonal Communication is a basic skill that individuals must possess because with the skills, an individual will be able to convey messages to others and can establish relationships with others (Ni'mah Suseno, 2009). In an individual's life one needs to socialize and create and maintain close relationships with others, and therefore, we spend a lot of personal time communicating with others. Furthremore, it is able to change the attitudes and behaviors of others with persuasive efforts, and so, the interpersonal communication can be used to achieve this goal. The the interpersonal communication situations is important because the process allows dialogue to take place. (Wijaya, 2013).

Based on the aformentioned explanation, it can be concluded that communication skills are the ability of individuals to convey their ideas which are packaged in the form of messages, and definitely it aims to make the message understood by the recipients of the message 
(communicant). As a result, a communicator is required to be creative and so, the communication can run effectively.

As an academic community, lecturers and students at Budi Luhur University Jakarta are called to play an active role in shaping the youth character of the nation's next generation through the Community Service activities. The Community Service is definitely an activity to bridge the world of education with the community. The mastery of knowledge owned by the academic community is meaningless if it is not implemented in the community.

Furthermore, the target community of this community service program is the foster youth of the National Education Care Foundation located in Ciledug, Tangerang. There are several reasons why it chose the foster youth of the National Education Care Foundation as the target community for the Community Service activity plan. Firstly, the young people who are under the care of the National Education Care Foundation are those with less fortunate family backgrounds. There are orphans, those who dropout of school due to their disable parents to send their children to the next level of education, and those from a mediocre economic class in society. It frequently makes them insecure or inferior. The foster youth of the National Education Care Foundation do not understand that each individual has his/her own potential. If it recognized and developed, it will be an effort to lead a better life. Secondly, the foster youth of the National Education Care Foundation have the right to have the opportunity to better understand the basics of leadership and organization. Thirdly, the foster youth of the National Education Care Foundation are a group of young people who have high enthusiasm for progress despite they are aware that their parents do not have sufficient economic capacity to take formal education.

\section{METHODS}

In this service program, it can be realized in a kind of involving the foster youth of the Nation Education Care Foundation located in Ciledug, Tangerang. This community service is carried out with several activities. These include:

1. Observations, introductions between the implementing team and the chairman of the National Education Care Foundation. In the meeting, the implementing party from the Faculty of Communication Sciences, Budi Luhur University has been obtained data on the focus of the activities in the National Education Care Foundation located in Ciledug, Tangerang.

2. Interviews with the National Education Care Foundation, have been conducted informally and quite intensely whether it is in a kind of face-to-face ways and communication media, such as mobile phones.

3. Teaching in a way of delivering materials from lecturers, alternately providing the materials of the Basic Leadership Training (LDK) on character building based on kebudiluhuran values

\section{RESULTS AND DISCUSSION}

The community Service Activities that the lecturers of Faculty of Communication Sciences, Budi Luhur University have carried out, deliberately raise the theme of "Character Building Based on Intelligence and Kebudiluhuran". This theme is considered appropriate because the target community in the Community Service activities are the foster youth of the National Education Care Foundation located in Ciledug, Tangerang.

There are several reasons when selecting the theme. Firstly, character building is important when introducing and getting used to positive things that individuals can apply in society. In this matter, the character building is the main responsibility of those whose profession are educators. Secondly, the targets of the Community Service activities are young people, most of whom are under the age of 20. The most appropriate age for introducing the character building is when they remain children and adolescents. At this age stage, they are easily directed and formed in a positive direction. Finally, when building character, it is very important to be in line with religious values, norms and moral rules in society. It is because the intellectual intelligence is not enough if it is not balanced with emotional intelligence (kebudiluhuran) and spiritual intelligence.

From the considerations, the implementing team decided that the activities to be carried out were in a form of Basic Leadership Training. This forum teaches participants about the basics of leadership and organization. Therefore, the main objective of the activities is achieved, i.e. to shape the personality and build the basic skills of good leadership and organization, and therefore, it supports the youth character in accordance with the principle of nobility (kebudilihuran).

The output target of carrying out the Community Service activities has been achieved, i.e. instilling the character-building values based on the principles of kebudiluhuran among the foster youth of the National Education Care Foundation located in Ciledug, Tangerang in a kind of implementing the Basic Leadership Training (LDK) for three (3) days at Villa Budi Luhur, Cisarua, Bogor.

Efforts to build character are carried out through the material debriefing and it is delivered through the two-way communication. Besides being supported by power points and interesting pictures, the presented material not only relates to leadership and organization, but also those about youth with the Islamic religious approach, the concept of intellectual and emotional intelligence, and youth related to a political approach.

As with the Basic Leadership Training (LDK) activities, there are creative games that can establish a fun atmosphere but still contain the character-building content, particularly regarding the leadership and organization. The reason for the similarity of the leadership and organization is how to achieve common goals through self-potential 
development. Organizations without leadership are meaningless, and vice versa. Leadership is meaningless if it is not in an organization and although the simplest organization is the family.

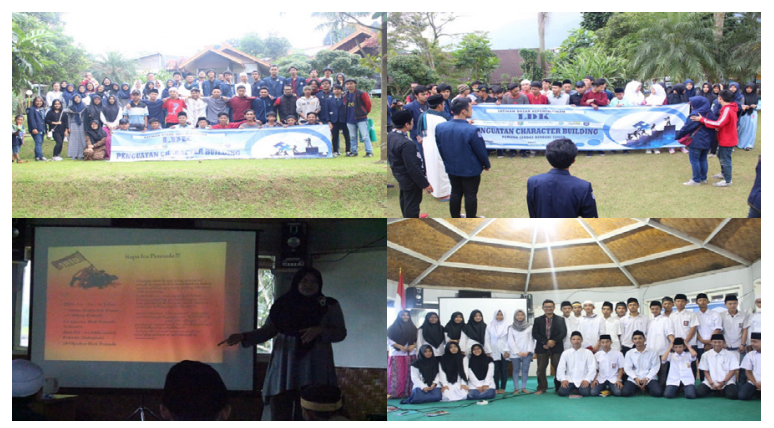

Picture 1. Activity documentation

\section{Discussion}

Character is an individual's character, morals or personality which is formed from the internalization of various virtues that he/she believes in and uses as a basis for his/her perspective of thinking, behaving, and acting. There are several ways in the process of character building in children and adolescents. These include providing character education in schools, introducing and getting used to positive things that can be applied and carried out in a community environment. Therefore, to form or build positive character, a planned and serious effort is needed, and it is known as character education. (Latihan Soal: Konsep Dan Karakteristik Perkembangan Peserta Didik, n.d.).

If the character education is only given to children or adolescents who attend formal education institutions, so what about children or adolescents who cannot go to school due to their parents' economic limitations? Therefore, lecturers and students at Budi Luhur University Jakarta were affected to carry out the Community Service activities with the theme of "Character Building Based on Intelligence and Kebudiluhuran" for the foster youth of the National Education Care Foundation located in Ciledug, Tangerang. The foundation shelters less fortunate children or adolescents.

The lecturers and students of the Faculty of Communication Sciences, Budi Luhur University, Jakarta, chose to carry out the Basic Leadership Training (LDK) as an effort or a process to instill positive things in children or adolescents. The program aims to build character that is in accordance with moral norms and rules in society. The positive things in question are noble values (kebudiluhuran).

There are two things as the focus in the Basic Leadership Training (LDK) as part of the process of character building based on intelligence and kebudiluhuran, i.e. the introduction stage and the understanding stage. At the introduction stage, the participants of the Basic Leadership Training (LDK) were introduced to positive things or good things, such as noble values (kebudiluhuran). This stage aims to instill positive values in the memory of the LDK participants. Therefore, the lecturers who acted as the bearers of the LDK materials related to character building provide more real examples and these can be practiced in future. At the understanding stage, moreover, the LDK material presenters provided direction or understanding of the good deeds having been introduced previously. The LDK participants will know and consciously practice noble values (kebudiluhuran) in the family and in the community.

In addition to receiving material on the character building based on intelligence and kebudiluhuran, the LDK participants as the foster youth of the National Education Care Foundation also received materials on Islam related to technology and Islam as Rahmatan Lil 'Alamin (a mercy to all creation). Because the implementing team realizes that intellectual intelligence is not enough if it is not accompanied by emotional intelligence and spiritual intelligence.

The LDK participants were provided online media literacy material because the foster youth of the Nation Education Care Foundation are a generation that naturally use online media (the native generation). Literacy is very much needed and therefore, the LDK participants will be able to choose and sort out which information is suitable for consumption and not. They are not only passive users, but also they are critical users of online media with virtuous character. It is expected that the participants will not access negative content, but they can produce something through online media uses. And if they can use online media wisely and intelligently, many benefits can be obtained and one of which can create a better future through the creation of works that are beneficial to society.

The stage of introduction and understanding of the character building based on intelligence and kebudiluhuran is not only limited to content in the presentation and discussion materials. The implementation team has designed several interactive games with such contents. Moreover, the participants who were involved in this interactive game indirectly got the basics of leadership and organization (teamwork) to achieve the desired goals together.

The participants were definitely enthusiastic about participating in the interactive game. In addition to creating a relaxed and fun atmosphere, the participants also got to know each other more closely. Gradually a sense of cohesiveness, mutual cooperation, togetherness and teamwork develops to complete the game with the best score.

What is interesting about this Basic Leadership Training (LDK) is that there are congregational worship activities in the schedule of events, such as praying in congregation starting from the Fajr prayer to the Isha prayer. Even before the time for the Fajr prayer, the participants together held Qiyamullail or sunnah prayers, such as the sunnah taubah prayer, the sunnah prayer tahajjud and the salatul Hajat. Finally, the participants 
proceeded with reading the Quran together, such as reading Surah Al Waqia (The Inevitable), Surah Yaseen (Yaseen), Surah Ar Rahmaan (The Beneficent) and Surah Al Mulk (Sovereignty).

\section{CONCLUSION}

Personality is definitely a picture of human attitudes and behaviors. In general it is reflected in their words and actions. Personality is a pattern of habits compiled into self and used to react and adapt to all stimuli both those that come from inside and outside.

In an effort to disseminate information about communication skills and abilities, lecturers and students of Communication Science have a strategic position. As intellectuals, lecturers and students have a moral responsibility to contribute to the surrounding community. The target community for this service program is the foster youths of the National Education Care Foundation located in Ciledug, Tangerang. This Community Service activity plan carries the theme, "Character Building based on Intelligence and Kebudiluhuran"

The output target of carrying out the Community Service activities has been achieved, i.e. instilling the characterbuilding values based on the principles of kebudiluhuran for the foster youth of the National Education Care Foundation located in Ciledug, Tangerang through the implementation of LDK for three (3) days at Villa Budi Luhur, Cisarua, Bogor.

\section{REFERENCES}

Cangara, H. (2014). Pengantar Ilmu Komunikasi (Edisi Kedua). Rajawali Press.

Latihan Soal: Konsep Dan Karakteristik Perkembangan Peserta Didik. (n.d.).

Suseno, MN. (2009). Pengaruh Pelatihan Komunikasi Interpersonal Terhadap Efikasi Diri Sebagai Pelatih pada Mahasiswa The Effect of Interpersonal Communication Training in Improving Self Efficacy as a Trainer Among College Students. 1(1), 93-106.

Effendy, OU. (2006). Ilmu Komunikasi; Teori dan Praktek. Remaja Rosda Karya.

Pradika, MI., Giyarsih, SR., and Hartono, H. (2018). Peran Pemuda Dalam Pengurangan Risiko Bencana Dan Implikasinya Terhadap Ketahanan Wilayah Desa Kepuharjo, Kecamatan Cangkringan, Kabupaten Sleman, Daerah Istimewa Yogyakarta. Jurnal Ketahanan Nasional, 24(2), 261-286. https://doi. org/10.22146/jkn.35311

Simbolon, M. (2008). Persepsi dan kepribadian. Jurnal Ekonomi Dan Bisnis, 2(1), 52-66. https://jurnal. unai.edu/index.php/jeko/article/view/516

Wijaya, IS. (2013). Komunikasi Interpersonal Dan Iklim Komunikasi. Jurnal Dakwah Tabligh, 14(1), hal.118-120. http://journal.uin-alauddin.ac.id/index. php/tabligh/article/view/318/283 